\title{
Opportunistic Infections in Acquired Immune Deficiency Syndrome Result from Synergistic Defects of Both the Natural and Adaptive Components of Cellular Immunity
}

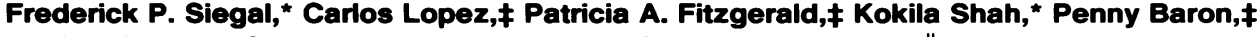 \\ Ira Z. Leiderman,\$ Domenica Imperato, “ and Sheldon Landesman" \\ *Division of Hematology-Oncology, Long Island Jewish Medical Center, New Hyde Park, New York 11042; †Herpesvirus Laboratory, \\ Memorial Sloan-Kettering Cancer Center, New York 10021; §Division of Clinical Immunology, Mount Sinai School of \\ Medicine, New York 10029; "Division of Infectious Diseases, Department of Medicine, State University of \\ New York/Downstate Medical Center, Brooklyn, New York 11203
}

\begin{abstract}
We evaluated the cellular immunity of 408 clinically stratified subjects at risk for acquired immune deficiency syndrome (AIDS), to define the role of interferon-alpha production deficits in the pathogenesis of opportunistic infections (OI). We followed 115 prospectively for up to $45 \mathrm{mo}$. Onset of OI was associated with, and predicted by, deficiency both of interferon-alpha generation in vitro, and of circulating Leu-3a+ cells. Interferonalpha production is an index of the function of certain non- $T$, non-B, large granular lymphocytes (LGL) that are independent of $T$ cell help. Leu-3a + cell counts are a marker of $T$ cell function. OI did not usually develop until both of these mutually independent immune functions were simultaneously critically depressed, leading to a synergistic interaction. These data suggest that the AIDS virus affects a subset of LGL, and that cytokine production by these cells is an important component of the host defense against intracellular pathogens that becomes crucial in the presence of severe $T$ cell immunodeficiency.
\end{abstract}

\section{Introduction}

The acquired immune deficiency syndrome (AIDS) ${ }^{1}$ is characterized by progressive failure of the immune system eventuating in opportunistic infections (OI) or neoplasms. Clinical, laboratory, and epidemiologic experience from the beginning of the AIDS epidemic indicated that a very broad spectrum of immunologic perturbation follows infection with the causative

Presented in part at the International Conference on AIDS, Centers for Disease Control, Atlanta, GA, April 1985.

Address reprint requests to Dr. Siegal. Dr. Lopez' present address is Viral Exanthems and Herpesvirus Branch, Centers for Disease Control, Atlanta, GA 30333. Dr. Fitzgerald's present address is Department of Pathology, New Jersey College of Medicine and Dentistry, Newark, NJ 07103.

Received for publication 2 December 1985.

1. Abbreviations used in this paper: AIDS, acquired immune deficiency syndrome; CNS, central nervous system; ELISA, enzyme-linked immunosorbent assay; HSV, herpes simplex virus; HTLV-III, human Tlymphotropic virus-III; IFN, interferon; LAV, lymphadenopathy associated virus; LGL, large granular lymphocytes; NK, natural killer cells; OI, opportunistic infections; PHA, phytohemagglutinin.

J. Clin. Invest.

(C) The American Society for Clinical Investigation, Inc. 0021-9738/86/07/0115/09 \$1.00

Volume 78, July 1986, 115-123 agent (1-7). These observations have now been consolidated by the recognition that virtually all such persons share serologic evidence for infection with certain exogenous human retroviruses $(8-11)$.

We previously reported a close association between the presence of OI and failure of cells from AIDS patients to produce interferon (IFN-alpha) (12). The significance of this in vitro assay is that it reflects the function of a $\mathrm{T}$ cell-independent population of large granular lymphocytes (LGL), rather than of T cells (13). Moreover, as the release of IFN-alpha in our system is independent of prior immunization state, it can be regarded as reflecting a "natural," rather than "adaptive" component of the immune system (14). T and B cells, in contrast, comprise the adaptive immune system, proliferating and differentiating in response to specific antigens. Defects of the $T$ cell limb of immunity are already widely accepted as critical to the immune compromise in AIDS.

The purpose of this prospective study was to better define the role of IFN-alpha production in the host defense against infection by intracellular pathogens, and to place abnormalities of IFN-alpha production in the context of other defects of cellmediated immunity. The approach we used was to define immune dysfunction in stratified cohorts of members of the "high risk groups" (15) and their intimate contacts, and having identified those (on clinical grounds) thought to be at high risk of eventual $\mathrm{OI}$, to follow them serially. We have so far observed 115 adult patients for as long as 45 mo.

The studies suggest that failure of both adaptive ( $T$ cell) and natural (LGL) components of cell-mediated immunity is necessary before OI develop.

\section{Methods}

Patients. Subjects for study were accessioned at Mount Sinai Medical Center (MSMC), SUNY/Downstate Medical Center, and Long Island Jewish Medical Center (LIJMC) in New York City. They either fulfilled the clinical criteria for AIDS as defined by the Centers for Disease Control, Atlanta, GA (CDC) (15), or were seen by one of us and considered, on the basis of clinical findings and epidemiologic background, to fall within the AIDS spectrum (Table I). Normal (healthy) control subjects, not known to be in AIDS risk groups, worked at MSMC, LIJMC, or Memorial Sloan-Kettering Cancer Center (MSKCC) as physicians, laboratory technicians, office and nursing personnel. 23 subjects served as infection controls, having, among other specific infections, varicella, viral pleuropericarditis, localized pulmonary infection with Mycobacteriaceae $t u$ berculosis hominis, and recurrent Herpes simplex. As a group they did not differ significantly from the normal control subjects. They were not analyzed further or included among the other controls.

Patient stratification. Subjects were stratified solely according to cri- 
Table I. Subjects of Study

\begin{tabular}{|c|c|c|c|c|}
\hline Risk group & Male & Female & $\begin{array}{l}\text { Studied } \\
\text { serially }\end{array}$ & $\begin{array}{l}\text { Stage change* } \\
\text { to OI observed }\end{array}$ \\
\hline Homosexual/bisexual & 239 & 0 & 80 & 25 \\
\hline (known AIDS contacts) & (38) & & (13) & (4) \\
\hline IVDA & 33 & 17 & 2 & 1 \\
\hline Hemophiliacs & 8 & 0 & 4 & 2 \\
\hline Haitians & 41 & 15 & 10 & 5 \\
\hline \multicolumn{5}{|l|}{ Sexual contacts of: } \\
\hline IVDA with AIDS & 1 & 16 & 3 & \\
\hline Bisexual men & 0 & 6 & 4 & 0 \\
\hline \multicolumn{5}{|l|}{ Children: } \\
\hline of parent with AIDS & 2 & 3 & 2 & 0 \\
\hline of IVDA & 6 & 9 & 6 & \\
\hline Other§ & 8 & 4 & 4 & 1 \\
\hline Totals & 338 & 70 & 115 & 34 \\
\hline Normal controls & 124 & 78 & 30 & 0 \\
\hline
\end{tabular}

* Includes 19 of the 115 serially studied subjects and 15 others who were not tested serially but developed OI subsequent to initial stratification and testing.

$\ddagger$ IVDA, intravenous drug abusers.

$\S$ Includes 2 cases of AIDS associated with blood transfusion, 2 cases of AIDS without identifiable risk factors, 1 dentist exposed to a case of AIDS, 7 house staff or nursing staff stuck by needles from AIDS patients or worried about close contact.

teria of history and physical examination into categories A-E, as outlined in Table II. All such subjects analyzed from January 1979 to July 1984 were included in the preliminary screening phase of the study.

Serial study. Patients selected for serial investigation were those with whom communication could be readily maintained and who desired to participate in long-term followup. Of this group, $20 \%$ were staged as A, $20 \%$ as B, $28 \%$ as C, $15 \%$ as D, and $17 \%$ as $E$ when first seen. Most of the subjects so selected were homosexual men. The frequency of followup was determined by the investigators, based upon our estimate of the likelihood of developing OI; patients stratified to groups A and B were tested less frequently than were those in $C$ and $D$, who were studied every 1-3 mo, whenever possible.

Laboratory testing. The delayed-type hypersensitivity skin testing used was the "Multitest-CMI" system, kindly provided by Dr. Pinya Cohen of Merieux Institute, Miami, FL; normal values obtained for 16 control subjects were comparable to previously published series. This system permits simultaneous low-antigen-dose testing using seven standardized antigens and a medium control (16). Mononuclear cells were obtained and counted as described previously (3). T cells and their subsets were characterized using indirect immunofluorescence with monoclonal antibodies of the Leu-series kindly provided by Dr. Robert L. Evans, and sheep erythrocyte rosette formation (3). Lymphocyte proliferative response to phytohemagglutinin (PHA), concanavalin A, and pokeweed mitogen was assessed after $72 \mathrm{~h}$ of culture by the incorporation of tritiated thymidine, and the peak of the dose-response curve expressed as net counts per minute over unstimulated background (3). Natural killer (NK) cell activity against herpes simplex virus (HSV)-infected fibroblasts was determined by ${ }^{51} \mathrm{Cr}$ release after $14 \mathrm{~h}$ of incubation, and the herpesspecific activity determined by subtracting the cytotoxicity against uninfected target cells (12). Natural killing of K-562 cells was determined after $14 \mathrm{~h}$ incubation (17). Enrichment and depletion of $\mathrm{T}$ cell subsets employed the "panning" technique of Wysoki and Sato (18). IFN-alpha released into cell supernatants after 14-h exposure to HSV-related antigens expressed on the fibroblast surface was measured by inhibition of plaque formation with vesicular stomatitis virus (12). To confirm the adequacy of our clinical inclusion criteria, over the course of the study we obtained serologic analysis for antibodies to human T lymphotropic virus-III/ lymphadenopathy associated virus (HTLV-III/LAV), initially through
Table II. Clinical Staging of Exposed Subjects

\begin{tabular}{cll}
\hline Stage & History & Physical and laboratory findings \\
\hline A & $\begin{array}{c}\text { Probable exposure, no } \\
\text { symptoms* }\end{array}$ & None \\
B & As in stage A & $\begin{array}{c}\text { Lymphadenopathy, three or } \\
\text { more groups, and/or }\end{array}$ \\
& & splenomegaly \\
C & As in stage B but with & As in stage B; may be none. \\
& symptoms* & Also chronic folliculitis, \\
& & nonspecific facial dermatitis, \\
& & oral thrush, warts, \\
& & molluscum contagiosum, \\
& & Herpes zoster, ITP-like \\
& & syndrome \\
D & Usually as in stage C & Kaposi's sarcoma, systemic \\
& (sometimes without & lymphoma (NHL or HD), \\
& symptoms*) & CNS lymphoma, OI limited \\
& & to CNS (toxoplasma, \\
& & cryptococcosis), "AIDS \\
& & encephalopathy" \\
& & Systemic OI
\end{tabular}

* Symptoms include unexplained persistent or intermittent malaise, fever $>100^{\circ} \mathrm{F}$, night sweats, progressive loss of weight ( $>5 \%$ of baseline), chronic or persistent intermittent diarrhea, abdominal pain, polyarthritis or arthralgia, painful adenopathy, and (especially among Haitians) tuberculosis.

‡ Fitting criteria of Centers for Disease Control, Atlanta, GA (15). HD, Hodgkin's disease; NHL, non-Hodgkin's lymphoma; ITP, immune thrombocytopenic purpura.

CDC by enzyme-linked immunosorbent assay (ELISA) and radioimmunoprecipitation, and more recently in our own laboratories using a kit kindly provided by Genetic Systems Corporation, Seattle, WA.

Statistical analysis. For the several immunologic and hematologic determinations, mean and standard deviation were determined for each clinical stage. Logarithmic conversion was done for the proliferating systems (mitogen responses), and for IFN-alpha generation, before statistical operations were performed. The lower limit of normal for each test was taken as two standard deviations below the mean or geometric mean. Scatter diagrams were constructed for each function. Stages A-E were assigned arbitrary values of $1-5$, and regression lines plotted for each of the functions. Those with the most rapid slopes and closest correlations to linearity were analyzed further. Inspection of scatter diagrams revealed cutoff values for certain functions that were tested with two-by-two contingency tables for the significance of their relationship to the development of OI, using chi-square analysis and odds-ratios (19). Overall and infection-free survival curves were plotted using the product-limit method of Kaplan and Meier. Assessment of significance employed the chi-square or Mantel-Haenszel test, as appropriate.

\section{Results}

Correlation of various assays with stage of disease. Representative scatter diagrams are shown in Figs. $1 a-c$. Regression lines based on stratified results from all our data are summarized in Fig. 2. The functions that associated most closely with progression through our clinical categories were those relating to Leu-3a+ (helper) $\mathrm{T}$ cells (Fig. $1 \mathrm{a}$ ), and those relating to IFN-alpha production (Fig. 1 c).

As is evident from Fig. 2, counts of circulating Leu-3a+ cells demonstrated the sharpest decline with stage of disease: on av- 

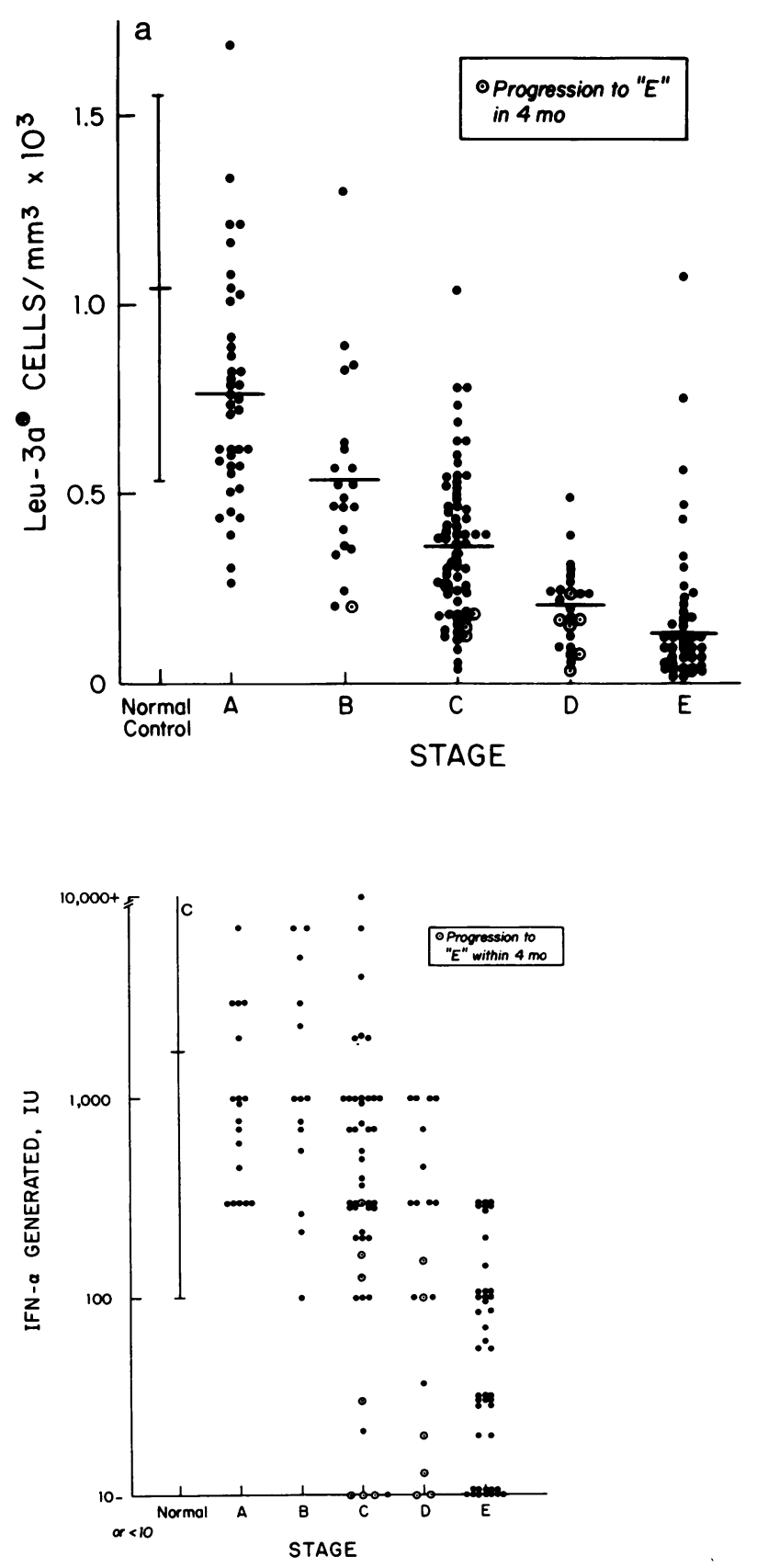

erage, progression from one stage to another was associated with a $17 \%$ reduction in the helper-inducer $\mathrm{T}$ cell subset. The slopes of leukocyte count, lymphocyte count, and absolute T cell count all reflected the fall in Leu-3a + cells; in each case, the slopes of these lines did not drop off as sharply as that of Leu-3a. Leu$2 a+$ cells showed a rise through the first three stages with a subsequent decline in D and E patients. PHA and concanavalin A responsiveness were closely negatively correlated to progressive disease, but inspection of the scatter diagrams (e.g., Fig. 1 b) indicated that the variability of results within each category, especially $E$, made the utility of individual data points in patient evaluation particularly difficult. Pokeweed mitogen responses were abnormal in almost all subjects having abnormal $\mathrm{T}$ cell subset ratios; they correlated less well with stage than did the other proliferation assays.

Notably, skin testing did not follow the pattern of gradual

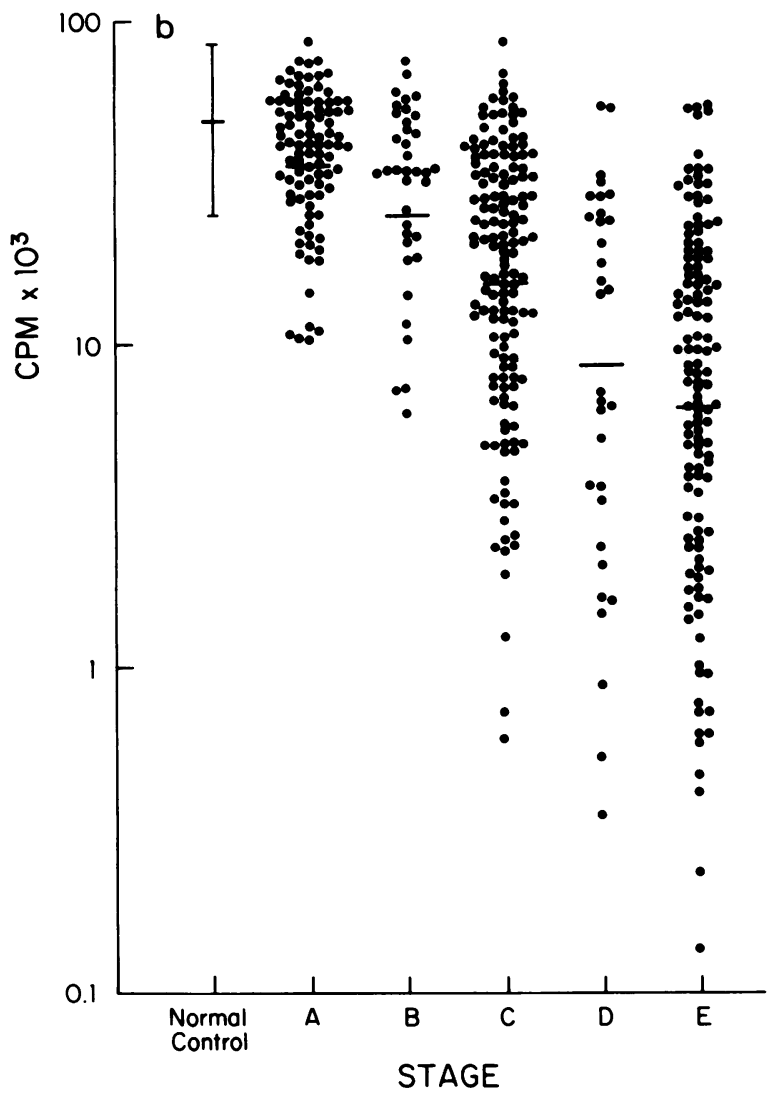

Figure 1. Representative scattergrams from screening phase of the study. These preliminary diagrams were constructed to define the data most likely to be useful as predictors of outcome. Fig. $1 b$ is a prototype for the regression lines in Fig. 2. Each data point represents a single determination on a patient in a particular stage; subjects may be shown more than once. For Figs. $(a)$ and $(c)$ the mean or geometric means of multiple data points within a stage for individual subjects were plotted. The horizontal axis for each is the clinical stage as defined in Table II. Vertical axes: $(a, b)$ T cell number and function expressed as ( $a$ ) circulating Leu-3a+ cells per $\mathrm{mm}^{3}$ (linear scale) and (b) peak of phytohemagglutinin dose-response curve, net counts per minute $\left[{ }^{3} \mathrm{H}\right]$ thymidine incorporation (log scale), (c) LGL function expressed as IFN-alpha generated in international units per $\mathrm{ml}$ culture supernatant (log scale). IFN concentrations in supernatants below 10 IU or above $10,000 \mathrm{IU} / \mathrm{ml}$ were considered to be 10 or $10,000 \mathrm{IU}$, respectively, for purposes of calculation and graphing.

fall by stage; category $\mathrm{D}$ patients showed remarkable preservation of delayed-type hypersensitivity: only one of six patients was anergic, as defined by total induration of $<8 \mathrm{~mm}$ with none of the seven antigens having $>1 \mathrm{~mm}$ induration in the Multitest assay. In contrast, anergy was present in 62 and $100 \%$ of $\mathrm{C}$ and E patients, respectively.

Indices of natural defense mechanisms were also found to decline with progression of disease. IFN-alpha generation (Fig. $1 \mathrm{c}$ ) demonstrated a rapid fall with stage of disease; there was a mean $10 \%$ drop in log IFN-alpha generation associated with progression through each stage. NK cell function using either K-562 cells or HSV-1-infected fibroblasts as targets was found to be normal in most patients irrespective of stage of disease. However, the means of both functions gradually declined with increasing stage. In contrast, monocyte counts were normal and their means stable across the AIDS spectrum. 

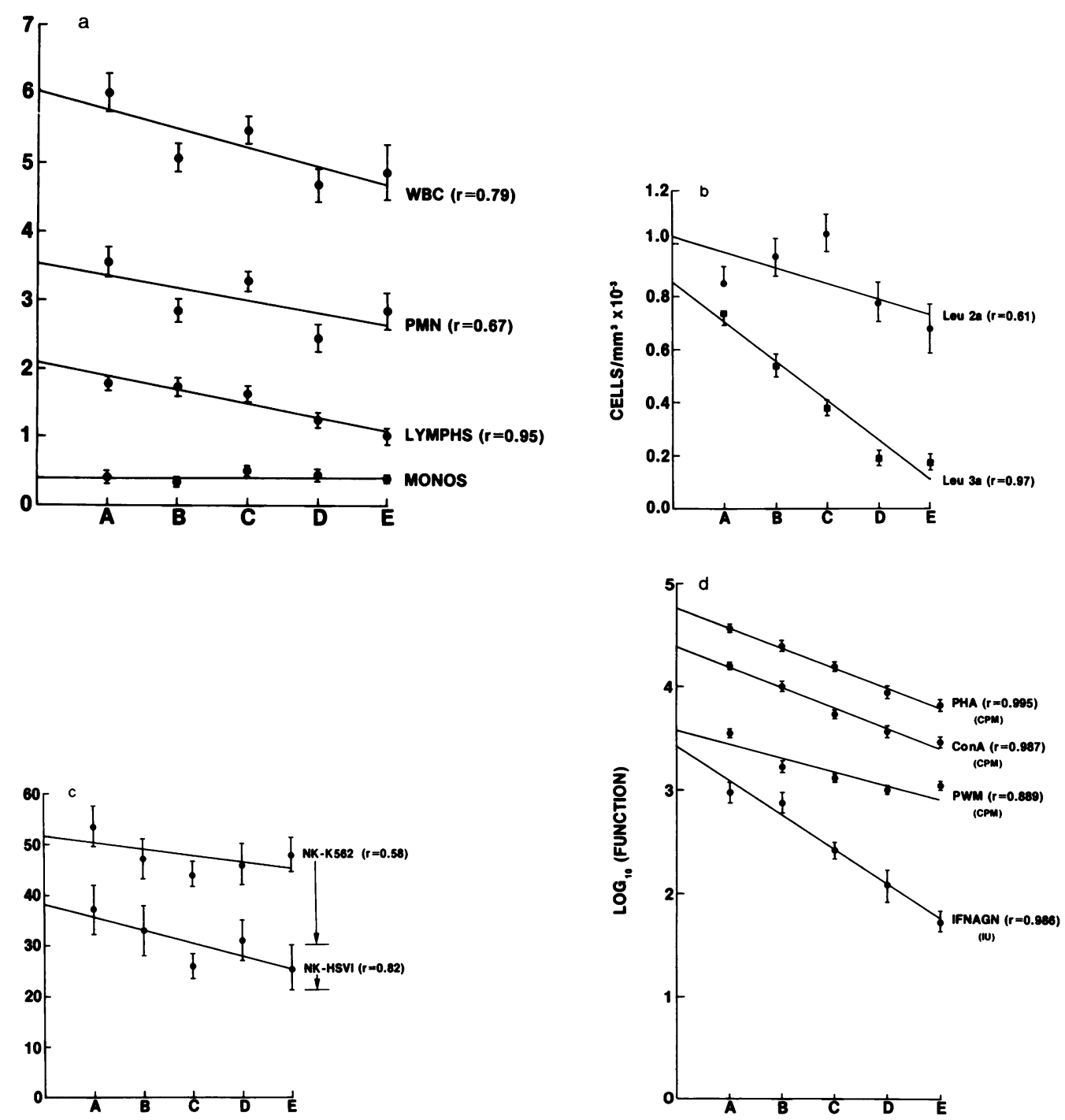

Figure 2. Regression lines for all hematologic and immunologic tests carried out on stratified subjects considered exposed to the AIDS agent. For each assay at each stage, the mean (or geometric mean for IFN-alpha generation, natural killing, mitogen responses) \pm 1 SEM is plotted on the abscissa. (a) Peripheral blood leukocytes: absolute leukocyte counts; ordinate $=$ cells $/ \mathrm{mm}^{3}$. WBC, leukocytes; PMN, granulocytes and bands; lymphs, lymphocytes; monos, monocytes. (b): T cell subsets; ordinate, cells $/ \mathrm{mm}^{3}$. Leu-2a, suppressor/cytotoxic subset; Leu-3a, helper/inducer subset. (c): Natural killing; ordinate, percent

Relationship of interferon-alpha generation to $T$ cells. The level of circulating Leu-3a+ cells, and the T cell subset (Leu-3/ Leu-2) ratio fell progressively with advancing stages of disease, as did IFN-alpha generation in vitro. If IFN-alpha generation were directly dependent upon the presence of helper-inducer $T$ cells, a close correlation should exist between them. For the patients studied, the coefficient of determination was $18.5 \%$, indicating that $<20 \%$ of the variance of $\log$ IFN-alpha generation was attributable to the absolute number or proportion of Leu$3 \mathrm{a}+$ cells. This observation was confirmed by experiments in which depletion of $\mathrm{T}$ cells by panning with a monoclonal antibody directed against all $\mathrm{T}$ cells (Leu-4) did not lessen the ability of the residual cell populations from normal controls to produce IFN-alpha (Table III). In other studies, the subpopulation of cytotoxicity at effector/target ratio of 50:1. NK-K562: K562 cell line as target; NK-HSV1: HSV-1-infected human fibroblasts (FS) as target. The lower limit of normal for each NK assay is indicated by the arrow and horizontal line at right. $(d)$ : Proliferative responses to plant lectins PHA, concanavalin A (Con A), pokeweed mitogen (PWM); ordinate, log counts per minute (cpm) and in vitro interferon-alpha generation (IFNAGN); ordinate, log international units (IU). For each regression line, the correlation coefficient $(r)$ is indicated.

LGL responsible for IFN-alpha generation was shown to be distinguishable from $T$ cells, $B$ cells, monocyte-macrophages, and NK cells by cell surface markers and by centrifugation on discontinuous Percoll density gradients (13, Fitzgerald, P. A., Mendelsohn, M., and Lopez, C., unpublished data). These studies demonstrate that IFN-alpha production in our assay is independent of the presence of $\mathrm{T}$ cells.

Relationship of Leu-3a+ cell counts to development of $\mathrm{OI}$. Inspection of the scatter diagram (Fig. $1 a$ ) for stage $\mathrm{E}$ and for stages A-D for those patients who later developed to stage E revealed that most $\mathrm{E}$ cases, and all who were later to develop OI from an earlier stage, had circulating Leu-3a+ cell counts below $250 / \mathrm{mm}^{3}\left(2.5 \times 10^{8} /\right.$ liter $)$. Contingency table analysis for this (Table IV) and two similarly plausible cutoff values of $\mathbf{3 0 0}$ 
Table III. Production of IFN-alpha by Mononuclear Cell Fractions

\begin{tabular}{lcc}
\hline & $\begin{array}{l}\text { Effect of depletion or enrichment of T cells } \\
\text { by the pan-T monoclonal antibody, Leu-4 }\end{array}$ \\
\cline { 2 - 3 } Cell fraction* & Experiment 1 & Experiment 2 \\
\hline & $I U / m l$ & $I U / m l$ \\
Lymphocytes & 3000 & 700 \\
Leu-4 negative & $>10,000$ & 3000 \\
Leu-4 positive & 200 & 100 \\
\hline
\end{tabular}

* Normal mononuclear cells were passaged through nylon wool to deplete adherent cells and separated into Leu-4 positive and negative fractions by panning before stimulation with HSV-1-infected fibroblasts at a 50:1 effector:target cell ratio (see Methods).

and $200 / \mathrm{mm}^{3}$ (data not shown) confirmed that there was a statistically significant relationship between reductions of these cells and OI; 250 gave the closest association $\left(P<5 \times 10^{-9}\right)$. Analyzing only for those subjects in categories A-D when tested, the same cutoff value was statistically associated with onset of $\mathrm{OI}$ within 4 mo of the test $\left(P<8 \times 10^{-9}\right)$, suggesting that a level of 250 Leu-3a+cells $/ \mathrm{mm}^{3}$ or less can be considered predictive of serious infectious disease.

Relationship of IFN-alpha production to development of $O I$. Inspection of the scatter diagram for IFN-alpha generation (Fig. $1 \mathrm{~b}$ ) suggested cutoff values might also be used for this function. Deficits of IFN-alpha production, at or below levels of both 100 $\mathrm{IU} / \mathrm{ml}$ (2 SD below the geometric normal mean; data not shown) and $300 \mathrm{IU} / \mathrm{ml}$ (Table V), were also closely associated with $\mathrm{OI}$ $\left(P<7 \times 10^{-9}\right)$. Analysis identical to that for Leu-3a+ cells revealed that this LGL function was also predictive $(P<3$ $\times 10^{-5}$ ) of intracellular infectious processes meeting the case definition for AIDS.

Both LGL and T cell dysfunction coexist when, or before, $O I$ develop. We asked whether these two independent components of cell-mediated immunity must both be significantly abnormal for AIDS patients to develop OI. Table VI shows this relationship. Subjects were categorized as having both functions critically depressed if they ever simultaneously had IFN-alpha production 300 IU or less (Table V) and circulating Leu-3a+ cells at 250/ $\mathrm{mm}^{3}$ or less (Table IV). We did not observe spontaneous recovery

Table IV. Relationship of Circulating

Leu-3+ Cells to Susceptibility to OI

\begin{tabular}{lcc}
\hline & Leu-3a+cell counts & Leu-3a+cell counts \\
\hline & $\mathrm{mm}^{3}$ & $\mathrm{~mm}^{3}$ \\
For all subjects: & $\leq 250$ & $>250$ \\
OI & 47 & 7 \\
No OI & 22 & 118 \\
\multicolumn{2}{c}{ Chi-square $=86.5, P<5 \times 10^{-9}$} \\
For A-D subjects: & 12 & 0 \\
OI within 4 mo & 22 & 118 \\
No OI in 4 mo & Chi-square $=45.22, P<8 \times 10^{-9}$
\end{tabular}

Table V. Relationship of IFN-alpha

Production to Susceptibility to OI

\begin{tabular}{lcc}
\hline & IFN-alpha generation & IFN-alpha generation \\
\hline & $I U / m l$ & $I U / m l$ \\
For all subjects: & $\leq 300$ & 300 \\
OI & 57 & 0 \\
No OI & 32 & 53 \\
\multicolumn{2}{c}{ Chi-square $=56.71, P<7 \times 10^{-9}$} & \\
For A-D subjects: & 13 & 0 \\
OI within 4 mo & 32 & 53 \\
No OI in 4 mo & Chi-square $=17.65, P<3 \times 10^{-5}$ & \\
\end{tabular}

to better than critical levels once they had both been reached, although other subjects sometimes transiently reached critically low levels of one or the other test, only to return to normal.

The majority of adult subjects having one or the other (usually interferon production), or neither, assay depressed below these critical levels remained uninfected during the period of followup. In sharp contrast, the majority of those with both functions depressed eventually developed OI. Chi-square analysis of the contingency table (Table VI) indicates a lack of homogeneity (chi-square $=82.14$ with 6 degrees of freedom, $P \ll 10^{-5}$ ). The cumulative risk of infection for those subjects with both functions depressed was $45 / 51(0.88)$. The risks for patients with only low IFN-alpha generation, or only low Leu-3+ cells, respectively, were $2 / 29(0.07)$ and $0 / 5(0)$. Dividing the risk of infection for each of these categories by the risk of infection for those with neither function depressed (1/30), estimated risk ratios (RR) of 26.5 (both depressed), 2.07 (IFN-alpha generation only), and 0 (Leu-3a only) are obtained. Only the RR for both measures depressed is significantly greater than unity $\left(P<2 \times 10^{-6}\right)$. Because the estimated RR for both measures depressed is considerably greater than the product of the RR for either critical depression alone, synergy between these two independent functions, on a multiplicative scale, is present (19).

Survival and infection-free survival of patients with severe and less severe cellular immune deficits. Figs. $3 a, b$ show the probability of survival and infection-free survival for three classes of subjects: ( $a$ ) those who never fell below either T cell or IFNalpha cutoff point, $(b)$ those who had or developed deficits of only one or the other, and $(c)$ those who simultaneously devel-

Table VI. Association of OI with Simultaneous Depression of $T$ Cell Counts and Interferon-alpha Generation (IFNAGN)

\begin{tabular}{lllll}
\hline & \multicolumn{2}{l}{ Test below critical level* } & \\
\cline { 2 - 4 } OI present? & Both & $\begin{array}{l}\text { IFNAGN } \\
\text { only }\end{array}$ & $\begin{array}{l}\text { Leu-3a } \\
\text { only }\end{array}$ & Neither \\
\hline $\begin{array}{l}\text { At time of } \\
\text { testing }\end{array}$ & 26 & 2 & & \\
$\begin{array}{l}\text { After testing } \\
\text { Total OI }\end{array}$ & $\frac{19}{45}$ & $\frac{0}{2}$ & 0 & 1 \\
None & 6 & 27 & 0 & 0 \\
& & & 5 & 1 \\
\hline
\end{tabular}

$*$ IFNAGN $\leq 300$ IU, Leu-3a $\leq 250 / \mathrm{mm}^{3}$. 
oped deficits of both, at any time during the study. Patients who developed low values for both criteria at any point in their followup period had a significantly poorer prognosis than those who did not; the point at which $50 \%$ of these subjects developed infection came at 10 mo of followup; $50 \%$ died within 12 mo. From the time that critical depression of both functions was first identified, $50 \%$ were infected within 4-5 mo, and were dead within 10 mo (data not shown). These plots include data taken until we began to use prophylaxis against Pneumocystis carinii pneumonia in subjects with critical depression of both functions.

\section{Discussion}

We undertook the present study to pursue the observation that reduced in vitro production of IFN-alpha by patients' mononuclear cells was closely associated with, and possibly contributing to, the development of the severe OI that define AIDS (12). We wished to clarify, through a prospective study, whether the interferon defect plays a role in permitting the development of clinically important intracellular infections, or is simply reflective of a response to these infections.

Release of IFN-alpha in our system, stimulated by herpesviruses or HSV-infected target cells, is independent of prior immunization $(14,20)$. IFN-alpha is made as well by cells taken from children and adults who have never been infected by the stimulating virus as it is by the cells of those who are seropositive and immune at the level of the $\mathrm{T}$ cell. Consequently, IFN-alpha production can be considered to reflect a natural, rather than an adaptive, component of the cellular host defense. In contrast, $\mathrm{T}$ cell production of IFN-gamma and other lymphokines only occurs in cells derived from immunized individuals and depends on the presence of primed $\mathrm{T}$ cells $(20,21)$. This is an expression of adaptive immunity, detectable only after the antigen-specific clonal selection and expansion characteristic of $\mathrm{T}$ and $\mathrm{B}$ cells.

Experiments included in this study (Table III) add to an increasing body of data (13, 14, Fitzgerald, P. A., M. Mendelsohn, and C. Lopez. Submitted for publication.) indicating that most IFN-alpha generation by peripheral blood mononuclear cells is a function of non-T, non-B lymphoid cells that are morphologically large and granular, are physically separable on Percoll density gradients or by other techniques from $\mathrm{T}$ cells, B cells, and monocytes, and distinct from NK cells by surface marker criteria (13). The interferon activity produced is neutralized by antibodies against alpha, but not gamma interferons, and is released promptly after cellular contact with virus, in contrast to the slower kinetics associated with maximal IFN-gamma production by $T$ cells $(13,21)$. Because of these special features, IFN-alpha production appears to be a functional marker for a distinct subset of mononuclear cells that might play an essential role in cellular immunity.

Our experimental strategy was to observe clinically staged patient groups to define which immune functions seemed most closely related to progression through the AIDS spectrum, and to focus our attention on those patients we thought likely to worsen from prodromal phases to fulfill the CDC's definition for AIDS with OI. Of the patients for whom adequate followup was available, 34 made such a transition, and permitted analysis of the period prior to the development of OI. The majority of these subjects remained stable; as shown in Fig. 3 (representing the subgroup for whom we had data for both Leu-3a and IFNalpha) more than half appear to have better than an $85 \%$ prob- ability of survival at 36 mo. Retrospectively, sera from most of our subjects have been tested for antibody to HTLV-III/LAV by ELISA; more than $90 \%$ of those within the population at highest risk of transition to infection (groups B-D) were strongly seropositive; only $71 \%$ of those in group A were positive.

We confirmed that severe compromise of $\mathrm{T}$ cell numbers and functions, on the one hand, and IFN-alpha production, on the other, were individually closely associated with the later development of OI. Examination of available data indicated, however, that those patients who had one, but not the other type of deficit did not have a significantly increased tendency toward later infections. In contrast, those with both $\mathrm{T}$ cell and IFNalpha production deficits generally went on to develop OI. This interaction is statistically significant, as compared with the effects of either dysfunction alone, indicating that a synergistic effect is involved. The overall impression is therefore that these functions will together be compromised before the severe infections associated with AIDS manifest themselves. This supports the idea that interferon-producing LGL are an essential component of "cell-mediated immunity" and might complement the T cellmacrophage interactions that were elegantly defined by Mackaness and his colleagues (22) over a decade ago.

IFN-alpha, one of several cytokines produced by LGL, augments the differentiation or activation of several effector cell types thought to participate in natural resistance, including monocyte-macrophages (23), NK cells (24), killer (K) cells of antibody-dependent cellular cytotoxicity (25), and those cells producing IFN-alpha (26). IFN-alpha production by LGL thus would be expected to be an important mediator and regulator of natural cell-mediated immunity. Production of IFN-alpha may be a marker for competence of an LGL subset crucial to the host defense. It could reflect the natural defense system's counterpart to the production of lymphokines, especially IFNgamma, other macrophage activating factors, and macrophage migration inhibitory factor by antigen-stimulated $T$ cells $(20$, 21), which also attract, hold, and activate effector cells at sites of infection.

Our results suggest that at least two overlapping but independent mechanisms normally exist in humans for activating effector cells of cell-mediated immunity. So long as either one persists, the host remains resistant to overwhelming attack by the external milieu. This idea is reminiscent of other aspects of the immune system, in particular the complement cascade, in which two quite separate systems with different evolutionary histories and degrees of specificity for antigens can each activate the effector pathways beyond C3 (27).

Although many of the patients who exhibited very severe immune dysfunction had concurrent $\mathrm{OI}, 19$ of 51 in this category became ill only 1-18 mo after both "critical" deficits became apparent; half of their case-defining OI developed 4-5 mo or more after the low test results. Indeed, $52 / 80$ subjects (Table VI) with critically low levels of IFN-alpha production did not develop OI during the period of followup. Because of the several months of poor immune function seen in some of our patients before OI developed, and the lack of depressed IFN-alpha generation by the cells of otherwise normal subjects with acute infections, we believe that low results of interferon production are not consequent to, but rather are indicative of a predisposition to the intracellular infections of AIDS.

Another implication of this work primarily concerns the pathogenesis of AIDS itself. Inasmuch as non-T cell-dependent 


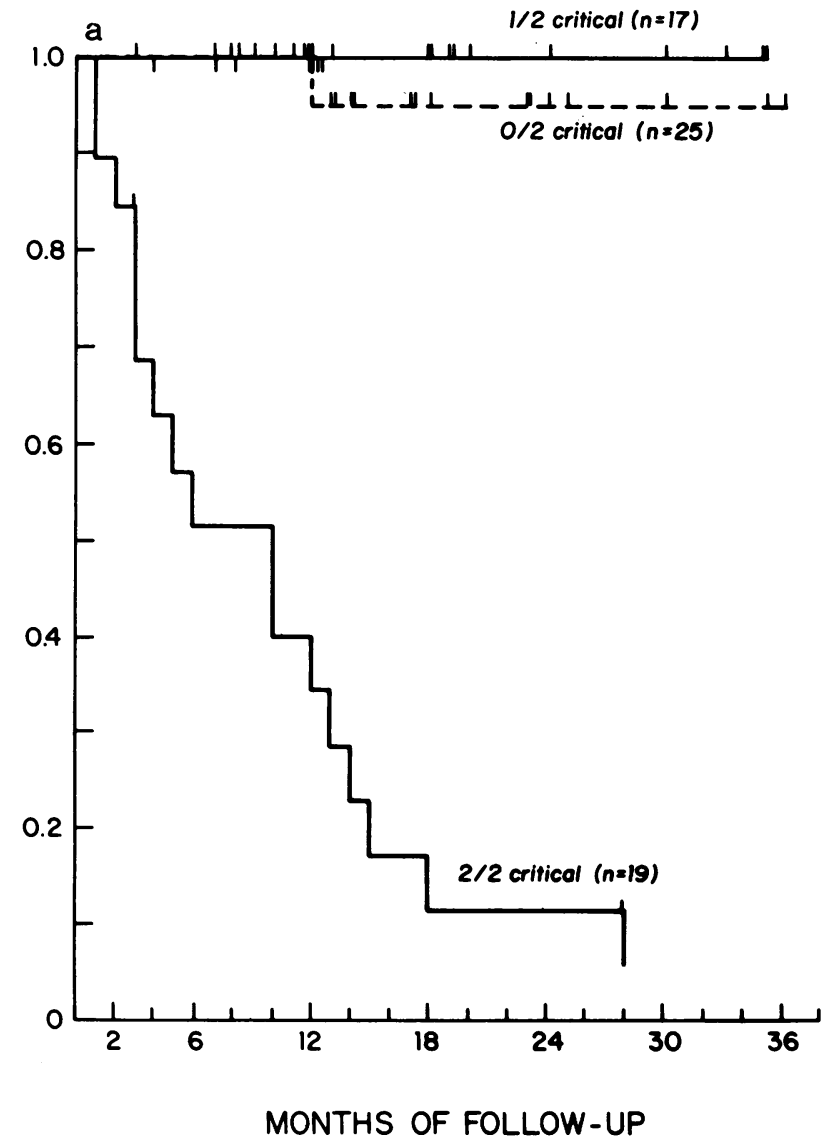

Figure 3. Kaplan-Meier survival curves for individual subjects with neither IFN-alpha generation nor circulating Leu-3a+ cells $(0 / 2)$ below "critical" values; those with one or the other $(1 / 2)$; or with both values $(2 / 2)$ reaching "critical" levels at any time during followup. Horizontal axis: months since patient was first studied. Vertical axis:

functions such as IFN-alpha production are affected in the disease, one can no longer consider AIDS simply to be defined by a paucity of "helper T cells." HTLV-III/LAV can target cells other than the Leu-3a+ $+(\mathrm{OKT}-4+) \mathrm{T}$ cell population. It is already known that $B$ cells can be infected in vitro by these retroviruses (28). Recent data suggest that thus far undefined brain cells can become involved, leading to the so-called "AIDS encephalopathy" (29), and that antigen-presenting dendritic cells (30) and macrophages (31) can harbor these viruses. Our data indicate that the retroviruses, directly or indirectly, also affect LGL. They may preferentially infect certain LGL subsets principally involved in cytokine production. Alternatively, LGL might be inhibited by a soluble suppressor factor analogous to those inhibiting helper $\mathrm{T}$ cells (32) or myeloid colony formation that have been reported to occur in AIDS-spectrum patients (33). These humoral mediators resemble those (e.g., p15[E]) found in cats infected with feline leukemia virus, which are retrovirus dependent and thought to be involved in the pathogenesis of the immunosuppression and hematopoietic dysfunction commonly observed in these animals (34). However, we have not yet been able to demonstrate suppression of IFN-alpha generation by coculture or incubation in either serum or cell supernatants from patients infected with HTLV-III/LAV (data not shown).

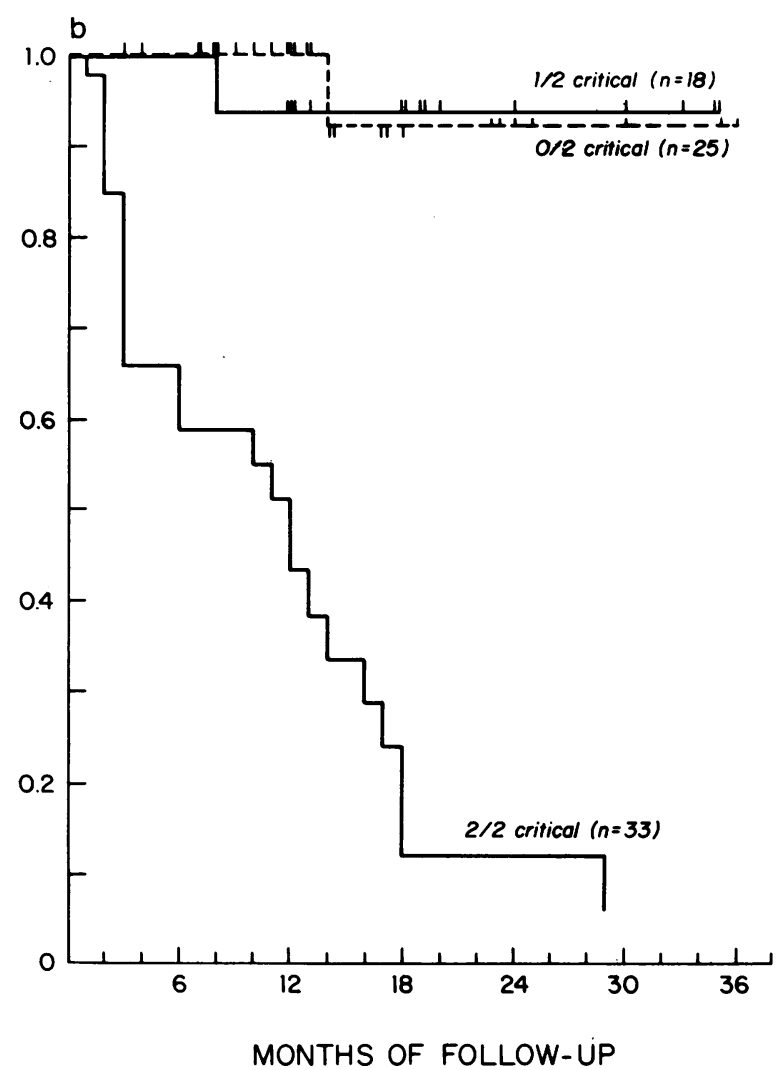

(a) probability of freedom from OI (excludes those subjects who already had infection at time of first study); (b) probability of overall survival. The upper two curves in each plot differ significantly from the lower curves $\left(P<10^{-4}\right)$.

The development of those manifestations of AIDS included in our category D (Kaposi's sarcoma, central nervous system [CNS] lymphomas, AIDS encephalopathy) frequently involved cellular immune deficiency that was less severe than that associated with systemic OI. Of note, delayed-type dermal hypersensitivity was preserved, relative to both stages $C$ and $E$, in this stage of disease, in contrast to the progressive declines by stage of most in vitro measures of immunity (Fig. 2). These results suggest that factors other than simple severity of the overall immunodeficiency, including genetic background (35), cytomegaloviruses (36), and the position of the CNS as an immunologically "privileged" site may play an interactive role in the development of certain clinical complications of retroviral infection. It is of note, however, that those subjects in category D who subsequently developed OI could be shown to have the worst in vitro deficits within the stage. This was also true for those patients considered to fall into earlier stages of disease.

Investigations are proceeding to develop effective therapy for AIDS. Drugs capable of inhibiting the replication of HTLVIII/LAV in vitro and in vivo are in early clinical trials. A reasonable endpoint for randomized clinical trials would be prevention of progression to OI. Such studies would be facilitated if they involved a cohort of subjects who are likely to develop 
severe OI within a predictably short period of time. Identification of patients having the combination of low absolute numbers of circulating helper $\mathrm{T}$ cells and reduced ability to generate IFNalpha would provide an ideal study group.

\section{Acknowledgment}

The authors wish to thank the many patients who, despite the difficulties associated with knowledge of exposure to, or serious illness from AIDS, continued to work with us. Special appreciation goes to Marta Siegal for laboratory supervision; Drs. Michael Marmor and Howard Thaler for biostatistical advice and analysis; John Weber and Kevin Gehan, Isabel Menendez, and Drs. Joseph Hassett, Michael Greenberg, Steven Litz, Asha Desai, Roberto Garcia, Jon Gold, and Susanne Campbell, RN for help with patient followup. Drs. Ciril Cabradilla, James Curran, and Donald Francis at the Centers for Disease Control provided much needed initial serologic data.

This work was supported by grants from the U. S. Public Health Service, AI-16186, CA-34989, CA-40527, CA-08748 and CA-35793, from The Chemotherapy Foundation, Dana Annenberg Hammond and the Irma T. Hirschl Charitable Trust.

\section{References}

1. Gottlieb, M. S., R. Schroff, H. M. Schanker, J. D. Weisman, T. F. Peng, R. A. Wolf, and A. Saxon. 1981. Pneumocystis carinii pneumonia and mucosal candidiasis in previously healthy homosexual men: Evidence of a new acquired cellular immunodeficiency. $N$. Engl. J. Med. 305:1425-1430.

2. Masur, H., M. A. Michelis, J. B. Greene, I. Onarato, R. A. Vande Stouwe, R. S. Holzman, G. Wormser, L. Brettman, M. Lange, H. W. Murray, and S. Cunningham-Rundles. 1981. An outbreak of communityacquired Pneumocystis carinii pneumonia: initial manifestation of cellular immune dysfunction. N. Engl. J. Med. 305:1431-1438.

3. Siegal, F. P., C. Lopez, G. S. Hammer, A. E. Brown, S. J. Kornfeld, J. Gold, J. Hassett, S. Z. Hirshman, C. Cunningham-Rundles, B. R. Adelsberg, D. M. Parham, M. Siegal, S. Cunningham-Rundles, and D. Armstrong. 1981. Severe acquired immunodeficiency in male homosexuals, manifested by chronic perianal ulcerative herpes simplex lesions. N. Engl. J. Med. 305:1439-1444.

4. Ziegler, J. L., W. L. Drew, R. C. Miner, L. Mintz, E. Rosenbaum, J. Gershow, E. T. Lennette, J. Greenspan, E. Shilltoe, J. Beckstead, C. Casavant, and K. Yamamoto. 1982. Outbreak of Burkitt's-like lymphoma in homosexual men. Lancet. ii:631-633.

5. Friedman-Kien, A. E., L. J. Laubenstein, P. Rubinstein, E. Buimovici-Klein, M. Marmor, R. Stahl, I. Spiglund, K. S. Kim, and S. Zolla-Pazner. 1982. Disseminated Kaposi's sarcoma in homosexual men. Ann. Intern. Med. 96:693-700.

6. Fauci, A. S., A. M. Macher, D. L. Longo, H. C. Lane, A. H. Rook, H. Masur, and E. P. Gelmann. 1984. NIH Conference: Acquired immune deficiency syndrome: Epidemiologic, clinical, immunologic and therapeutic considerations. Ann. Intern. Med. 100:92-106.

7. Hersh, E. M., P. W. A. Mansell, J. M. Reuben, A. Rios, and G. R. Newell. 1984. Immunological characterizations of patients with acquired immune deficiency syndrome-related symptom complex, and a related life style. Cancer Res. 44:5894-5901.

8. Barre-Sinoussi, F., J.-C. Chermann, F. Rey, M. T. Nugeyre, S. Chamaret, J. Gruest, C. Dauguet, C. Axler-Blin, F. Vezinet-Brun, C. Rouzioux, W. Rozenbaum, and L. Montagnier. 1983. Isolation of a T-lymphotropic retrovirus from a patient at risk for acquired immune deficiency syndrome (AIDS). Science (Wash. DC). 220:868-870.

9. Gallo, R. C., S. Z. Salahuddin, M. Popovic, G. Shearer, M. Kaplan, B. F. Haynes, T. J. Palker, R. Redfield, J. Oleske, B. Safai, G. White, P. Foster, and P. D. Markham. 1984. Frequent detection and isolation of cytopathic retroviruses (HTLV-III) from patients with AIDS and at risk for AIDS. Science (Wash. DC). 224:500-503.
10. Gonda, M., F. Wong-Staal, R. C. Gallo, J. E. Clements, O. Narayan, and $R$. V. Gilden. 1985. Sequence homology and morphologic similarity of HTLV-III and visna virus, a pathogenic lentivirus. Science (Wash. DC). 227:173-177.

11. Laurence, J., F. Brun-Vezinet, S. Schutzer, C. Rouzioux, D. Klatzmann, F. Barre-Sinoussi, and J.-C. Chermann. 1984. Lymphadenopathy associated viral antibody in AIDS. N. Engl. J. Med. 311:12691273.

12. Lopez, C., P. A. Fitzgerald, and F. P. Siegal. 1983. Severe acquired immune deficiency syndrome in male homosexuals: Diminished capacity to make interferon-alpha in vitro associated with severe opportunistic infections. J. Infect. Dis. 148:962-966.

13. Fitzgerald, P. A., T. E. Schindler, F. P. Siegal, and C. Lopez. 1984. Independence of interferon production and natural killer function and association with opportunistic infections in acquired immune deficiency syndrome. In Natural Killer Activity and its Regulation, T. Hoshino, H. S. Koren, and A. Uchida, editors. Excerpta Medica, Amsterdam. pp. 415-421.

14. Fitzgerald, P. A., P. von Wussow, and C. Lopez. 1982. Role of interferon in natural kill of HSV-1-infected fibroblasts. J. Immunol. 129: 819-823.

15. Centers for Disease Control. 1982. Update on acquired immune deficiency syndrome (AIDS)-United States. Morbid. Mortal. Weekly Rep. 31:507-514.

16. Knicker, W. T., C. T. Anderson, and M. Roumiantzeff. 1983. The multitest system: A standardized approach to evaluation of delayed hypersensitivity and cell-mediated immunity. Ann. Allergy. 43:73-79.

17. Fitzgerald, P. A., R. Evans, D. Kirkpatrick, and C. Lopez. 1983. Heterogeneity of NK cells: Comparison of effectors which lyse HSV-1infected fibroblasts and K562 erythroleukemia targets. J. Immunol. 130: 1663-1668.

18. Wysocki, L. J., and V. L. Sato. 1978. "Panning" for lymphocytes: A method for cell selection. Proc. Natl. Acad. Sci. USA. 75:2844-2848.

19. Kleinbaum, D. G., L. L. Kupper, and H. Morgenstern. 1983. Epidemiologic Research: Principles and Quantitative Methods, Lifetime Learning Publications, Belmont, CA. pp. 405-409.

20. Green, J. A., T.-J. Yeh, and J. C. Overall. 1981. Sequential production of IFN-alpha and immune-specific IFN-gamma by human mononuclear leukocytes exposed to HSV. J. Immunol. 127:1192-1196.

21. Murray, H. W., B. Y. Rubin, H. Masur, and R. B. Roberts. 1984. Impaired production of lymphokines and immune (gamma) interferon in the acquired immunodeficiency syndrome. N. Engl. J. Med. 310:883889.

22. Mackaness, G. B. 1970. The monocyte in cell-mediated immunity. Semin. Hematol. 7:172-184.

23. Stanwick, T. L., D. E. Campbell, and A. J. Nahmias. 1980. Spontaneous cytotoxicity mediated by human monocyte-macrophages against human fibroblasts infected with Herpes simplex virus. Augmentation by interferon. Cell. Immunol. 53:413-416.

24. Gidlund, M., A. Orn, H. Wigzell, A. Senik, and I. Gresser. 1978. Enhanced NK cell activity in mice injected with interferon inducers. Nature (Lond.). 273:759-761.

25. Trinchieri, G., D. Santoli, and H. Koprowski. 1978. Spontaneous cell-mediated cytotoxicity in humans: role of interferon and immunoglobulins. J. Immunol. 120:1849-1855.

26. Stewart, W. E., II. 1979. The Interferon System. Second ed. Springer-Verlag, New York.

27. Muller-Eberhard, H. J. 1983. Chemistry and function of the complement system. In The Biology of Immunologic Disease. F. J. Dixon, and D. W. Fisher, editors. Sinauer Associates, Inc., Sunderland, MA. pp. 129-138.

28. Montagnier, L., J. Gruest, S. Charmaret, C. Dauget, C. Axler, D. Guetard, M. T. Nugeyre, F. Barre-Sinoussi, J.-C. Chermann, J. B. Brunet, D. Klatzmann, and J.-C. Gluckmann. 1984. Adaptation of lymphadenopathy associated virus (LAV) to replication in EBV-transformed B lymphoblastoid cell lines. Science (Wash. DC). 225:63-66.

29. Shaw, G. M., M. E. Harper, B. H. Hahn, L. G. Epstein, D. C. 
Gajdusek, R. W. Price, B. A. Navia, C. K. Petito, C. J. O'Hara, J. E. Groopman, E. S. Cho, J. M. Oleske, F. Wong-Staal, and R. C. Gallo. 1985. HTLV-III infection of brains of children and adults with AIDS encephalopathy. Science (Wash. DC). 227:177-182.

30. Armstrong, J. A., and R. Horne. 1984. Follicular dendritic cells and virus-like particles in AIDS-related lymphadenopathy. Lancet. ii: 370-372.

31. Gyorkey, F., J. L. Melnick, J. G. Sinkovics, and P. Gyorkey. 1985. Retrovirus resembling HTLV in macrophages of patients with AIDS. Lancet. i:106-107.

32. Laurence, J., and L. Mayer. 1984. Immunoregulatory lymphokines of T hybridomas from AIDS patients: Constitutive and inducible suppressor factors. Science (Wash. DC). 225:66-69.

33. Leiderman, I. Z., M. L. Greenberg, B. R. Adelsberg, and F. P.
Siegal. 1985. An inhibitor of granulopoiesis in patients with acquired immune deficiency syndrome (AIDS). International Conference on Acquired Immune Deficiency Syndrome, CDC, Altanta, GA.

34. Hardy, W. D., Jr. 1984. Feline leukemia virus as an animal retrovirus model for the human T-cell leukemia virus. In Human T-cell leukemia/lymphoma virus. R. C. Gallo, M. E. Essex, and L. Gross, editors. Cold Spring Harbor Press, Cold Spring Harbor, NY. pp. 35-43.

35. Rubinstein, P., S. Rodriguez de Cordoba, R. Ostreicher, and A. Friedman-Kien. 1984. Immunogenetics and predisposition to Kaposi's sarcoma (EKS). UCLA Symposium on Molecular and Cellular Biology. (Acquired Immune Deficiency Syndrome). 16:309-318.

36. Giraldo, G., E. Beth, and E. S. Huang. 1980. Kaposi's sarcoma and its relationship to cytomegalovirus (CMV). III. CMV DNA and CMV early antigens in Kaposi's sarcoma. Int. J. Cancer. 26:23-29. 